\title{
Divorce and Its Psychological and Social Effects on the Children of Divorced People from Their Viewpoint in the Jordanian Society
}

\author{
Safia M Jabali ${ }^{1} \&$ Sami Salameh AL-Massarweh ${ }^{2}$ \\ ${ }^{1}$ Faculty of Educational Sciences Department of Child Education, Isra University, Jordan \\ ${ }^{2}$ Faculty of Arts, Department of Psychology, Isra University, Jordan \\ Correspondence: Safia M Jabali, Faculty of Educational Sciences Department of Child Education, Isra \\ University, Jordan.
}

Received: June 6, 2021

Accepted: February 7, 2022

Online Published: February 11, 2022

doi:10.5539/mas.v16n2p1

URL: https://doi.org/10.5539/mas.v16n2p1

\begin{abstract}
This study aimed to identify the psychological and social effects of divorce on children from their viewpoint, and to achieve the aim of the study A questionnaire was developed consisting of (17) items that were distributed to a sample of (100) children of the divorced, and they were randomly selected. The researchers used the descriptive and analytical method for the study. The study concluded that feeling fear and anxiety about the future and the accumulation of worries and diseases is one of the most psychological effects that children of divorced men are exposed to, and it leads the individual to a feeling of inferiority and lack of self-esteem. While the most social factors affecting the members of the study sample were that divorce leads children to bad company due to poor family control over them. Then society viewed them as an inferior view that they are not socially qualified. The results of the study also showed that there were no statistically significant differences attributed to the age or gender variable, while statistically significant differences appeared due to the scientific qualification variable.
\end{abstract}

Keywords: divorce, children of divorced people, psychological and social effects, Jordanian society, family disintegration

\section{Introduction}

Divorce is a social phenomenon since the emergence of humanity and the rise of ancient human civilizations, and its names have multiplied, such as separation, divorce, abandonment, neglect and others. Although divorce is a big problem that works to disintegrate the family and marital life, but sometimes it is a solution to marital problems for fear of exacerbating them and leading to crimes such as violence, suicide, rape and other sex. Project, mental illness, depression and other crimes and diseases are present in all societies, whether Arab or Western, and also in different religions (Al-Janabi, 1983). The social, economic, political and technological changes have played a major role in the disintegration of marital life and the increase in divorce cases, which generate negative effects on the individual, the family and society. The children of divorced people are the victims of divorce and family disintegration, as they face many problems such as frustration, anxiety and psychological diseases. And the phenomenon of divorce is not limited to a particular social class, but has become occurring in all classes, whether poor, rich, educated or uneducated, especially after the emergence of modern technology such as (the Internet, Facebook, Twitter) and other social networking sites that have played a prominent role in the instability of life. Marital status and the increase in divorce rates every year, both in the Arab community in general and the Jordanian society in particular as the cases of divorce for the year 2020 reached (22780) in the Jordanian society, according to what was stated by the Chief Justice Dr. Abdel-Hafez Al-Rabtah on Wednesday 3/2/2021 in a press conference. And that this phenomenon has become threatening the stability of the family and society, both in terms of social, economic and psychological (Khudair, 2004). Especially on the life of children, their upbringing, their care and their psychological, cognitive and behavioral development, and for this reason the phenomenon of divorce has become in need of treatment and attention through educational, social, psychological and legal studies carried out by a team of specialists and those interested in this field to work on rehabilitating and educating young people coming to marriage about the concept of marriage and its importance and the rights of each one They are for the sake of family cohesion and the success of marital life, which reduces divorce cases in society. 


\subsection{Study Problem}

The problem of divorce has become in the increase in divorce cases in the Arab community in general and the Jordanian society in particular, according to the statistics issued by official and private institutions in Jordan, and it has become a social, psychological and economic problem due to its negative effects on society, the family and children, and the problem of studying is summarized by knowing the psychological and social effects of divorce Which is reflected on the children from the point of view of the study sample.

\subsection{Importance of the Study}

This study derives its importance in theory in preserving the cohesion and cohesion of society by studying the phenomenon of divorce, which has become a major problem as a result of the rapid changes, cultural risks and revolution in the world of communication and technology, which leave negative effects on society and the children of divorced people as a result of family disintegration stemming from divorce. In practice, the results of this study will contribute to presenting a clear picture by knowing the most important psychological and social implications of divorced children, which helps decision-makers and officials who have a relationship with the issue of family and divorce in developing strategies and counseling and awareness programs for young people and couples to reduce divorce and make them aware of its effects and damages on the family and children And society.

\subsection{Study Questions}

1) What are the most important psychological effects of divorce that affect the children of divorced people?

2) What are the most important social effects of divorce that affect the children of divorced people?

3) Is there a statistically significant effect of the demographic variables (gender, age, educational qualification) from the viewpoint of the study sample individuals regarding the fields of study?

\subsection{Objectives of the Study}

1) Identify the most important psychological effects of divorce that affect the children of divorced people.

2) Identify the most important social effects of divorce that affect the children of divorced people.

3) Knowing is there a statistically significant effect of the demographic variables (gender, age, educational qualification) from the viewpoint of the study sample individuals regarding the fields of study.

\section{Limitations of the Study}

\subsection{Time Limit}

The study is limited to the psychological and social effects of divorce from the viewpoint of the children of divorced women for the 2020/2021 academic year.

\subsection{Place and Objective Limit}

This research is limited to determining the psychological and social effects of divorce, Capital Governorate (Amman).

\subsection{The Human Limit}

This research is limited to the children of divorced people in the Capital Governorate (Amman).

The results of the study are determined by the nature of the tool and its validity and reliability indications.

\section{Procedural Concepts}

Divorce: is the separation of the husband from the wife through verbal or writing, and its official approval by the Sharia judge and its registration.

Psychological effects: every negative behavior that affects the psyche of the child as a result of divorce.

Social effects: all social behavior affected by the child's marital status as a result of divorce.

Divorced: They are the husband and wife separated from each other officially by the judge of the Sharia court.

Children of divorced: They are the children of the husband and wife separated from each other officially by the judge of the Sharia court. 


\section{Idiomatic Concepts}

Sharia divorce: raising the marriage immediately or in the event with a specific wording, in other words meaning: dissolving the marriage bond and ending the marital relationship, and divorce is called single will (Al-Sartawi, 2012: 169).

The definition of the United Nations: A court ruling separating the spouses gives each of them the right to remarry according to the laws followed in their countries (Al-Shalabi, 1992).

\section{Theoretical Framework and Previous Studies}

\subsection{Factors Leading to Divorce}

A. Cultural and social factors: Cultural and social factors are represented by values, customs, traditions, religion, language, social systems, ethics, economic, social, cultural, political and technological changes that play an important role in destabilizing the social structure and family disintegration that generates divorce through the different concepts of the spouses, such as the difference in character, socialization, interference of the couple's family and bad relationship, Whereas, the bad relationship between husband and wife may be one of the reasons leading to divorce, especially when each husband or wife tries to impose their views on the other and the difference in the role of women through increasing educational and work opportunities and the emergence of feminist movements to demand equality between men and women, as there are also other factors that lead to Divorce, such as poor choice, moral corruption, marital infidelity, frigidity in the husband or wife, work of women, neglect of marital duties, non-procreation, social class differences, etc. (Shukri et al., 2011).

B. Psychological factors: These are the psychological variables that are related to the human personality of the individual mainly, especially the motives, emotions, instincts, the absence of feelings of love, affection, and affection between them, and the coercion in choosing a husband or wife, and early marriage may generate psychological effects on the spouses such as quarrels and tensions between them and the lack of satisfaction of sexual desire as a result of the psychological effects that occur when Husband to hate her body after her birth or pregnancy without Considerate the physiological changes that happens to the wife and perhaps bad words from both parties, or the disease of the husband or wife.

C. Economic factors: The poor economic situation and family unemployment may prevent the continuation of married life because of the living requirements that the spouses cannot provide, especially since most women have the desire to buy and shop in imitation of girlfriends, relatives and celebrities, which makes them look for work to help the husband, and this may lead to neglecting the affairs of her home And her children at the expense of her new social position at work, the failure of marriage to be based on sound foundations, and the difference between husband and wife in their outlook on life and the level of culture and social status (Al-Khashab, 1985).

D. Technological factors: The modern means of communication and social media sites such as Facebook, Twitter and the Internet have played a major role in the disintegration of marital relations and divorce despite their importance, especially among groups of young people who have become rebellious through them against the behaviors, values and social trends recognized, generating depression and isolation (Al-Zubaidi et al., 2009). It also led in many cases to the disintegration of social and family relations and distrust between the spouses, causing separation from each other, and some studies indicated that the high rate of divorce was due to the use of social networking sites through messages and pictures of sexual and emotional temptation, introverted isolation and suspicion between the spouses (Al-Khaqani, 2015).

\subsection{Psychological and Social Effects on Divorced Children}

Psychological effects: Children may be born as a result of divorce worries and their feeling of fear and anxiety about the future and the society's view of them as divorced children, and there have been cases as a result of this feeling of fear and others subjected to psychological problems such as introversion and isolation from people as well as losing the sympathy of tenderness as a result of being away from the mother's tenderness if they are with the father and the tenderness of the father If they are with the mother, the divorce also affects the psychological and physical health of the children, especially if they are five or six years old this is due to the lack of interest of their parents in them as a result of family problems, and viewing of both parties or one of them is through family and social centers and institutions, which leads to a decline in children's morale, such as crying, despair, anxiety, trouble and the need for financial matters this is because the father and mother lose their livelihood (Khudair, 2004).

The child as a result of divorce is affected by problems and ruptures that have a negative impact on the child, family and society. Among these effects: The child has internal conflicts as a result of the breakdown of family 
life, so this child carries aggressive motives towards parents and the rest of society. In many cases, the child moves from the headquarters of the broken family to live strangely with his father or mother, and thus faces great difficulties in adapting to the stepmother or stepfather. The child may make several comparisons between his parents and the new parents, which makes him in a state of continuous psychological disorder. According to this new situation, the child must adapt to different home environments in terms of economic, social and cultural levels which affects the child's personality greatly he creates a personality unstable, and oscillating. like parents, the child bears the burden of constantly thinking about the problem of separation. The child draws continuous comparisons between his disintegrating family and the family life that the rest of the children live, which generates a feeling of frustration, or it may win him an aggressive tendency towards everyone, especially children of healthy families. The child is exposed to disorder and anxiety as a result of his lack of awareness of the underlying goals of the conflict between the parents or the reasons for trying to use it - by his parents - to launch an attack on each other and use it as a tool to achieve victory over the other side. This disorder in childhood leads to a disturbance in the emotional and mental development of the child, so that a person with a shaky or ailing personality emerges to society, which harms the entire society (Al-Jaafari, 1999).

Social effects: Divorced children may be affected by the negative view of society towards them in terms of behavior, behavior, disappointment and frustration expected for them in the future, which increases them only complication and fear of the future, and the separation of the father from the mother may affect the early socialization of children in the first years of his life that leads to disintegration and homelessness As a result of the lack of direct supervision of children by parents and living in the streets, homelessness, delinquency, and their loss of a sense of security, protection and stability, and this makes them think as a result of these conflicts, dropping out of schools, deviation in behavior, weak self-confidence, inability to intellectual development and social interaction with their friends, and their deprivation of proper social upbringing They resort to homelessness and the use of drugs and intoxicants to keep away from the concerns of the family, and all of this is one of the negative effects that divorce leaves on the children (Ahmed, 2001).

Among the most important social effects on children is also family disintegration, which works to loosen the bonds of family building, weak social interactions between family members, disturbance of expectations of their roles, feelings of alienation and insecurity, and this is the result of the social changes that society is going through (Al-Shabiki, 2006). Divorce also generates negative effects on children, such as losing the breadwinner and financial source, increasing economic pressures, and also the parental life of guidance, knowledge, counseling and assistance through parents, as children who live with their parents have more financial expenses than the spouses are separated as a result of limited income and financial resources after divorce. For both spouses, this will affect the livelihood of the children in terms of education, quality of schools, housing, health care, and relationship with friends (Teachman and Paasch, 1994).

\section{Previous Studies}

Al-Zahrani (2021), this study aimed to identify the relationship of emotional divorce with psychological stress and self-efficacy among a sample of couples in Jeddah, Saudi Arabia. The researcher used the descriptive correlative approach, the emotional divorce scale, the spouses' psychological stress scale, and the self-efficacy scale. The study sample consisted of (198 husbands and wives), and the results of the study found a positive relationship between psychological stress and emotional divorce. While there was a negative relationship between self-efficacy and emotional divorce, and there were also differences between the averages of both husbands and wives in being affected by psychological stress in favor of the wives' sample. There are no differences between husbands and wives in the level of self-efficacy. And the presence of a significant effect of the high level of psychological stress, And the low level of self-efficacy in predicting the emergence of emotional divorce in spouses. Najdawi's study (2018) aimed to try to understand the phenomenon of emotional divorce in Jordanian society, where the study was conducted on an intentional sample consisting of (17) women who reported emotional divorce. The researchers used the qualitative approach through an in-depth interview to collect data one of the results of this study was that emotional divorce exists in Jordan and it is difficult to accurately identify its numbers. One of the reasons for this divorce was the difference in expectations in marriage for both spouses, the concept of marriage for men and women, cultural factors, and the prevalence of individualism among men. And one of the reasons that pushed the woman to accept the matter reality and continuation of this marriage not to request an official divorce is to preserve the social image and fear for the future of children and parents. Rababaa study (2015) aims to find out the causes of divorce and its treatment in Jordan from the point of view of divorced people and legal judges. The study sample consisted of and (30) legal judges and (60) divorced people in all governorates of Jordan. The researchers used the descriptive, analytical and interview method to collect information the results of the study concluded that the most important factors for 
divorce are poor choice at a rate of $(83 \%)$, interference by the wife's family by $(77 \%)$, interference by the husband's family by $(70 \%)$ and failure to perform the wife's rights to the husband at a rate of $(63 \%)$. A Kheira Study (2015) It aimed to identify the self-image of children of divorce by highlighting the defect that children of divorce suffer in their perception of their self-image by studying this phenomenon on three cases of adolescents who are victims of the divorce of their parents through the application of a set of tools from observation, interview and GPS testing one of the most important results of this study was that children of divorce suffer from a feeling of anxiety, tension, excitement, feelings of deprivation, a sense of inferiority and insecurity, and the feeling of difference creates a feeling that makes them think that people look at them differently this makes the teenager frustrated and lack of confidence in social relationships, especially if he was at a young age. A study (Vitanen, 2014) in the United States of America, entitled The Divorce Revolution and Generalized Trust: Evidence from the United States 1973 - 2010, the study clarified the relationship between marriage laws and trust in society. As easy as what is known as the culture of easy divorce, whenever individuals have less confidence in society, which in turn will be reflected in social cohesion on the one hand, and affiliation and loyalty to society on the other hand. The issue of trust, whether on the individual level (self-confidence) or on the social level (confidence in society), its value and criteria are extremely important, and therefore the results of this study are in agreement with many studies conducted in the United States on confidence in society and the factors affecting it. A study (Valenzuela et al., 2014) Social network sites, marriage well-being and divorce Survey and state-level evidence from the United States: This study aimed to reveal the relationship between the use of social networks and marital happiness on the one hand, and divorce rates on the other hand, and its correlation with social networks. The results showed that the increased use of social networks has a negative relationship on marital happiness. And it works to increase and raise the level of problems in marital relations, and thinking about the divorce decision. The results of this study are in agreement with the results of the national study that was titled Facebook from 2008-2010. The study found that the increase in social media websites increases divorce rates directly in various parts of the United States with different factors causing divorce, and the two studies also focused on how to convert negative factors for social communication into positive factors. Masoud's study (2013) aimed to identify the most important (social, economic and psychological damages resulting from divorce for girls in the early stage of marriage in slums, And testing the practice of the meaning treatment model with Islamic content in the service of the individual to mitigate the harms resulting from divorce for girls in the early stage of marriage in slum areas, and The researchers relied on more than one tool consistent with the nature and quality of the study, such as the questionnaire and the interview, and the study community was one of the divorced women who hesitated to the Model Association for Service. The individual, family and society, and the study sample consisted of 127 cases who meet the conditions, The researchers reached several results, the most important of which are: The problems dealt with in that study within the framework of the meaningful treatment model for social problems due to poor relations with her family, frequent blame for her and family monitoring of her actions, and economic problems such as the financial burdens that the family bears on the newly married divorced woman as a result of separation from the husband. Divorce, psychological problems, and psychological stress that falls on divorced women and isolation as a result of society's view of them. The study of the Sheikh and others (2013) aimed at identifying the causes of the phenomenon of divorce and its implications, and the proposed solutions to treat this phenomenon. The study tool was questionnaires distributed on a sample consisting of (62) divorced (husband and wife) from the community of Medina, The most important results of this study: The most important social reasons for divorce are the lack of dialogue within the family in a democratic manner, as well as marriage imposed by families, and culturally the main reason for divorce is to watch programs contrary to customs and values through the media, and the most important psychological reasons leading to divorce It is infidelity, and the most important religious reason was the failure to respect the rights of the spouses to marital rights and duties.

\subsection{What Distinguishes the Study from Previous Studies}

Previous studies talked about divorce and its factors, and the implications for both spouses and children, such as the study (Sheikh et al., 2013; Masoud, 2013), and the studies also showed the most important effects on children of divorce, such as the study (Khaira, 2015). The current study agreed with most of the studies on the factors leading to divorce, such as (Al-Najdawi study 2018, and the fourth in 2015) and the implications for children, such as the study (Khair, 2015). This study was distinguished from previous studies by knowing the implications for children due to divorce. 


\section{Method and Procedures}

\subsection{Study Methodology}

The researchers used the descriptive and analytical approach to conduct this study, due to its blameness with the nature of the study.

\subsection{Study Population}

The study population consisted of children of divorced people of different genders, groups and age qualifications in the Capital Governorate (Amman).

\subsection{Study Sample}

A random sample of 100 children of divorced people was selected in the Capital Governorate (Amman). directly and also through social media via electronic questionnaire It is as follows:

Table 1. Study sample members according to demographic variables

\begin{tabular}{llll}
\hline Variable & Categories & Iteration & Percentage \\
\hline Sex & Male & 54 & $54 \%$ \\
& Females & 46 & $46 \%$ \\
Lifetime & Under 18 years of age & 44 & $44 \%$ \\
& $18-25$ years & 20 & $20 \%$ \\
& More than25 years & 36 & $36 \%$ \\
\multirow{5}{*}{ scientific qualification } & Secondary and below & 56 & $56 \%$ \\
& bachelor's degree & 30 & $30 \%$ \\
& Graduate & 14 & $14 \%$ \\
\hline
\end{tabular}

\subsection{Study Tool}

The study tool consisted of a questionnaire containing (17) paragraphs that were applied to a number of divorced children in order to find out the psychological and social effects of divorce on children by reviewing the theoretical concepts and previous studies that are related to the topic. The level of the answer for each paragraph will be graded according to (the five Likert scale) And defining them in five levels as follows: very agree and give (5) grades and a level in agreement and gives (4) degrees and a neutral level and gives (3) degrees and a level that does not agree and gives (2) two degrees and a level that does not agree strongly and gives (1) one degree, and a scale Judging the results divided into (high, medium, low), depending on the tool categories.

\subsection{Tool Validation}

The researchers carried out to verify the validity of the tool presenting the tool to a number of arbitrators specialized in the field of psychology, education, Islamic law and sociology, in order to know what the paragraphs measure, and the extent of the scale's relevance to the variables to be measured.

Tool stability:

The values of stability transactions (Cornbach Alpha) were extracted for the study areas and were as follows:

Table 2. Stability transaction values (Cornbach Alpha) for study areas

\begin{tabular}{lll}
\hline NO & Field & Stability factor \\
\hline 1 & Psychological effects & 0.77 \\
2 & Social implications & 0.84 \\
The tool as a whole. & 0.73
\end{tabular}

The results of the study showed a rise in stability transaction ratios, showing a high consistency between single-field paragraphs and the paragraphs of the tool as a whole. This makes them acceptable for scientific research purposes.

\subsection{Study Procedures}

The questionnaire was distributed to the study sample after explaining its objectives, and that their answers will be treated with complete confidentiality, and will be used only for scientific research purposes only. 


\subsection{Statistical Treatment}

For the purpose of answering the research questions and achieving the desired goals, the following statistical treatments were used:

1) To answer the first and second questions, the arithmetic means and standard deviations were extracted.

2) To answer the third question to extract the effect of gender, the T-Test was used for two independent samples. To extract the effect of age and scientific qualification, the One Way ANOVA test was used.

3) To extract the stability of the tool, the stability factor (Cornbach Alpha) was used.

4) Frequencies and percentages of sample count were extracted.

\section{Study Results and Discussion}

8.1 The Answer to the First Question: What are the Most Important Psychological Effects of Divorce that Affect Children of Divorced People

The mean and standard deviations of the answers of the study sample individuals were related to the field of: Psychological effects, and the results were as follows:

Table 3. Mathematical averages and standard deviations of the responses of study sample members to paragraphs that measure psychological effects

\begin{tabular}{|c|c|c|c|c|c|}
\hline No & Paragraph & $\begin{array}{l}\text { Arithmetic } \\
\text { average }\end{array}$ & $\begin{array}{l}\text { Standard } \\
\text { deviation }\end{array}$ & Rank & Grade \\
\hline 2 & $\begin{array}{l}\text { Fear and anxiety about the future and the accumulation of } \\
\text { worries and diseases. }\end{array}$ & 4.42 & 1.07 & (1) & High \\
\hline 4 & It leads the individual to feel inferior and unappreciated. & 4. 4 & 0.70 & 2 & High \\
\hline 3 & $\begin{array}{l}\text { The individual becomes vulnerable to people's ambitions and } \\
\text { accusations of moral deviations, leading him to isolation. }\end{array}$ & 4. 34 & 0.82 & 3 & High \\
\hline 7 & Divorce increases the likelihood of depression and frustration. & 4. 24 & 0.77 & 4 & High \\
\hline 5 & $\begin{array}{l}\text { The individual takes a negative reaction to future engagement } \\
\text { and marriage. }\end{array}$ & 4. 16 & 1.09 & 5 & High \\
\hline 1 & $\begin{array}{l}\text { Divorce is a direct cause of children losing confidence in } \\
\text { themselves. }\end{array}$ & 4. 08 & 0.97 & 6 & High \\
\hline 8 & The individual feels after security, protection and stability. & 4. 06 & 0.84 & 7 & High \\
\hline 6 & $\begin{array}{l}\text { The individual tends to be more violent and nervous as a } \\
\text { solution to most of the problems and obstacles they face. }\end{array}$ & 3.96 & 1.07 & 8 & High \\
\hline 9 & The individual feels independent and free from parental control. & 3.82 & 1.24 & 9 & High \\
\hline \multicolumn{2}{|c|}{ College degree } & 4. 16 & 63 & & High \\
\hline
\end{tabular}

It appears from the previous table that the arithmetic averages were high for the items according to the answers of the individuals of the study sample, and the total arithmetic mean came (4. 16), with a standard deviation of (.63). The previous table shows Paragraph No. (2) which states "a feeling of fear and anxiety about the future and the accumulation of worries and diseases" came in first place with an arithmetic average of (4.42), while each of Paragraph No. (4), which states "leads the individual to a feeling of inferiority." And not appreciating himself "in the second rank with an arithmetic average of (4.40), Paragraph No. (5) comes in the penultimate rank, which states "The individual tends to be more violent and nervous as a solution to most of the problems and obstacles he faces," with a mean arithmetic of (3.96), Paragraph No. (9) comes in the last rank, which states that "the individual feels independence and freedom away from parental control," with a mean of (3.82).

\subsection{The Answer to the Second Question: What are the Most Important Social Effects of Divorce that Affect the Children of Divorced People}

The arithmetic averages and standard deviations were extracted for the answers of the study sample individuals with regard to the second domain, which states: Social effects, and the results were as follows: 
Table 4. Mathematical averages and standard deviations of the responses of study sample members to paragraphs that measure social impacts

\begin{tabular}{|c|c|c|c|c|c|}
\hline No & Paragraphs & $\begin{array}{l}\text { Arithmetic } \\
\text { average }\end{array}$ & $\begin{array}{l}\text { Standard } \\
\text { deviation }\end{array}$ & Rank & Grade \\
\hline 7 & $\begin{array}{l}\text { Divorce leads children to bad company because of poor } \\
\text { control over them. }\end{array}$ & 4.4 & 0.70 & 1 & high \\
\hline 5 & $\begin{array}{l}\text { The individual (male and female) finds it difficult to bond in } \\
\text { the future. }\end{array}$ & 4. 36 & 1.08 & 2 & high \\
\hline 6 & Society views divorced children as socially ineligible & 4. 34 & 0.85 & 3 & high \\
\hline 3 & Divorce leads to habits that are unacceptable to society. & 4. 2 & 0.90 & 4 & high \\
\hline 1 & $\begin{array}{l}\text { Emotional deprivation and lack of tenderness lead to the } \\
\text { deviation of children. }\end{array}$ & 4. 08 & 0.97 & 5 & high \\
\hline 4 & The individual feels unacceptable and socially isolated. & 3. 98 & 0.96 & 6 & high \\
\hline 8 & $\begin{array}{l}\text { Divorce and lack of compassion for children lead to a } \\
\text { tendency towards violence. }\end{array}$ & 3.94 & 1.08 & 7 & high \\
\hline 2 & $\begin{array}{l}\text { There is an atmosphere of tension, discord and differences } \\
\text { between divorced children. }\end{array}$ & 3.88 & 1.30 & 8 & high \\
\hline \multicolumn{2}{|c|}{ College degree } & 4. 15 & .56 & & high \\
\hline
\end{tabular}

It appears from the previous table that the arithmetic averages were high for the items according to the answers of the individuals of the study sample, and the total arithmetic mean came (4. 15), with a standard deviation of (0.56).

The table shows that Paragraph No. (7) which states that "divorce leads to bad company of children due to poor supervision over them," came first with an arithmetic average of (4.40), While each of Paragraph No. (5), which states that "the individual (males and females) finds it difficult to relate in the future," came in the second rank with an arithmetic mean of (4.36), and it came in the rank before The last paragraph No. (8), which states that "divorce and lack of affection in children lead to delinquency towards violence," with an average arithmetic of (3.94), and came in the last rank, Paragraph No. (2) Which states, "An atmosphere of tension, discord and disagreements prevails between divorced children," Arithmetic average It reached (3. 88).

8.3 The Answer to the Third Question: Is There A Statistically Significant Effect of Demographic Variables (Gender, Age, Educational Qualification)

\subsubsection{First: Sex}

The T-test was used for two independent samples, and the results were as follows:

Table 5. Calculation averages, standard deviations and value $(\mathrm{t})$ to test the differences between the study sample answers attributable to the sex variable

\begin{tabular}{llllll}
\hline Field & Sex & $\begin{array}{l}\text { Arithmetic } \\
\text { average }\end{array}$ & Standard deviation & Value T & Indication level \\
\hline Psychological & male & 3.92 & .65 & .014 & .912 \\
effects & female & 4.36 & .56 & & \\
\multirow{3}{*}{ Social effects } & male & 4.00 & .62 & .098 & .301 \\
& female & 4.26 & .49 & &
\end{tabular}

Field The results of the study indicate that there are no statistically significant differences between the answers of the male and female respondents with regard to the different answers of the study sample individuals according to gender. Where the value of the level of significance in all areas of the study was not statistically significant at the level of significance $(\alpha \leq 0.05)$.

\subsubsection{Second: Age}

Arithmetic averages were extracted for the answers of the study sample individuals according to the age variable, and the answers were as follows: 
Table 6. Calculation averages and standard deviations of the responses of study sample members according to age variable

\begin{tabular}{llll}
\hline Field & Categories & $\begin{array}{l}\text { Arithmetic } \\
\text { average }\end{array}$ & Standard deviation \\
\hline Psychological effects & Under 18 years of age & 4.02 & 0.69 \\
& 18-25years & 4.41 & 0.28 \\
& More than 25 years & 4.37 & 0.54 \\
Social effects & Under 18 years of age & 4.16 & 0.63 \\
& 18-25 years old & 4.08 & 0.65 \\
& More than 25 years & 4.15 & 0.49
\end{tabular}

It appears from the table that there are apparent differences between the average answers of the study sample individuals depending on the age variable.

To find out if these differences are statistically significant or not, a One Way ANOVA analysis was performed, and the results were as follows:

Table 7. OneWay ANOVAanalysis to show the impact of age variable on the answers of study sample members

\begin{tabular}{|c|c|c|c|c|c|c|}
\hline Field & $\begin{array}{l}\text { Source } \\
\text { contrast }\end{array}$ & Total squares & $\begin{array}{l}\text { Degrees of } \\
\text { freedom }\end{array}$ & $\begin{array}{l}\text { Average } \\
\text { squares }\end{array}$ & Value(F) & $\begin{array}{l}\text { Level of } \\
\text { significance }\end{array}$ \\
\hline \multirow{4}{*}{$\begin{array}{l}\text { Psychological } \\
\text { effects }\end{array}$} & Between groups & 1.525 & 52 & .762 & 1.976 & .150 \\
\hline & Inside groups & 18.136 & 97 & .386 & & \\
\hline & Total & 19.660 & 99 & & & \\
\hline & Between groups & .391 & 52 & .195 & .617 & .544 \\
\hline \multirow[t]{2}{*}{ Social effects } & Inside groups & 14.881 & 97 & .317 & & \\
\hline & Total & 15.72 & 99 & & & \\
\hline
\end{tabular}

It appears from the table that the differences between the answers of the study sample members according to age were not statistically significant at the level of significance $(\alpha \leq 0.05)$ This indicates that there are no statistically significant differences between the answers of the study sample individuals due to the age variable.

8.3.3 Third: Academic Qualification

Arithmetic averages were extracted for the answers of the study sample according to the scientific qualification variable, and the answers were as follows:

Table 8. Mathematical averages and standard deviations of the responses of the study sample members according to the variable of scientific qualification

\begin{tabular}{llll}
\hline Field & Categories & Arithmetic average & Standard deviation \\
\hline Psychological effects & Secondary and below & 3.59 & .51 \\
& bachelor's degree & 4.41 & .43 \\
& Graduate & 4.05 & .75 \\
\multirow{3}{*}{ Social effects } & Secondary and below & 4.16 & .63 \\
& bachelor's degree & 3.82 & .37 \\
& Graduate & 4.41 & .33
\end{tabular}

It appears from the table that there are apparent differences between the averages of the responses of the study sample individuals depending on the scientific qualification variable, To find out if these differences are statistically significant or not, a One Way ANOVA analysis was performed, and the results were as follows: 
Table 9. Single Contrast Analysis (One Way ANOVA) to show the impact of the scientific qualification variable on the answers of the study sample members

\begin{tabular}{lllllll}
\hline Field & $\begin{array}{l}\text { Source } \\
\text { contrast }\end{array}$ & $\begin{array}{l}\text { Total } \\
\text { squares }\end{array}$ & $\begin{array}{l}\text { Degrees of } \\
\text { freedom }\end{array}$ & $\begin{array}{l}\text { Average } \\
\text { squares }\end{array}$ & Value (F) & $\begin{array}{l}\text { Level of } \\
\text { significance }\end{array}$ \\
\hline Psychological effects & Between groups & 4.064 & 52 & 2.032 & 6.123 & .004 \\
& Inside groups & 15.596 & 97 & .332 & & \\
& Total & 19.660 & 99 & & & \\
Social effects & Between groups & 3.361 & 52 & 1.681 & 6.631 & .003 \\
& Inside groups & 11.911 & 97 & .253 & & \\
& Total & 15.272 & 99 & & & \\
\hline
\end{tabular}

It appears from the table that the differences between the answers of the study sample members according to the difference in scientific qualification were statistically significant at the level of significance $(\alpha \leq 0.05)$ This indicates the existence of statistically significant differences between the answers of the study sample individuals due to the scientific qualification variable. To find out the source of these differences, a procedure was carried out shafih test, and the results were as follows:

Table 10. Xavier remote test to find out in favor of which categories were the differences between the members of the study sample according to the categories of the variable scientific qualification

\begin{tabular}{llllll}
\hline Field & scientific qualification & $\begin{array}{l}\text { Arithmetic } \\
\text { average }\end{array}$ & $\begin{array}{l}\text { Secondary and } \\
\text { below }\end{array}$ & $\begin{array}{l}\text { bachelor's } \\
\text { degree }\end{array}$ & Graduate \\
\hline $\begin{array}{l}\text { Psychological } \\
\text { effects }\end{array}$ & $\begin{array}{l}\text { Secondary and below } \\
\text { bachelor's degree }\end{array}$ & & & $.007^{*}$ & .208 \\
& $\begin{array}{l}\text { Graduate } \\
\text { Secondary and below }\end{array}$ & & $.033^{*}$ & .142 \\
Social effects & $\begin{array}{l}\text { Sachelor's degree } \\
\text { Graduate }\end{array}$ & & & $.011^{*}$ \\
& & & & .914
\end{tabular}

It appears from the table that the statistically significant differences were between My classes are secondary and below and bachelors degrees in the first field, As for the second field, the differences were between the secondary and lower categories, the bachelors degree, the secondary and lower categories, and the higher studies.

\section{Discussing the Results}

The results of the study concluded that the psychological factors that most affect the children of divorced people are the feeling of fear and anxiety about the future and the accumulation of worries and diseases. Then comes the individual's feeling of inferiority and lack of self-appreciation. The results of the study also found that the most social factors affecting the study sample members as a result of divorce are bad company due to poor control over them, difficulty in future association, and society's inferiority view towards divorced children as not being socially qualified. The results of the study also showed that there were no statistically significant differences due to the age or gender variable, while statistically significant differences appeared due to the scientific qualification variable.

\section{Study Recommendations}

1) Activating the role of family, social and educational institutions in directing and guiding those who are about to get married, such as family reform offices in Sharia courts in Jordan.

2) Educating young people about the rights of spouses in marital life and the negative effects of divorce on spouses, children and society.

3) Educating spouses about the importance of confidentiality and privacy in marital life, especially with regard to marital cohabitation.

4) Accustom the spouses to solve family disputes and problems on their own without the intervention of the spouses' family or reformers except in the case of necessity.

5) Rational thinking in choosing a husband or wife without the influence of family or friends in the selection process away from emotions, sexual instincts and shame when making the decision to approve the marriage.

6) Giving religion, morals, and social and educational values of great importance in the process of choosing a husband or wife. 


\section{References}

Ahmed, Soheir Kamel. (2001). Children's mental health. Alexandria Book Center, Alexandria, Egypt.

Al Khaqani, Laith. (2015). Social media and its role in family disintegration. Retrieved from https://annabaa.org/arabic/informatics/1400

Al-Jaafari, \& Abd al-Rahman bin Muhammad. (1999). The relationship of some family variables to juvenile delinquency in the Eastern Province of the Kingdom of Saudi Arabia. Journal of Security Research.

Al-Janabi, Aida. (1983). The social and cultural variables of the phenomenon of divorce. Department of Cultural Affairs and Publishing, Publications of the Ministry of Culture and Information, National Library, Baghdad.

Al-Khashab, \& Mustafa. (1985). Studies in family sociology (1st ed.). Arab Renaissance Publishing House, Beirut.

Al-Najdawi, Anne Musa. (2018). Emotional divorce in Jordanian society: A qualitative study. Social Sciences and Humanities Studies, 45(4). University of Jordan, Jordan.

Al-Sartawi, Mahmoud. (2012). Jurisprudence of Personal Status (1) (9th ed.). Al-Quds Open University.

Al-Shabiki, Al-Jazi Bint Muhammad. (2006). Social Problems of Poor Women in Saudi Society. Master Thesis King Abdulaziz University, Saudi Arabia.

Al-Shalabi, Fahum. (1992). Divorce in the Ramallah district. Social statistical study, Center for the Study and Documentation of Palestinian Society, Bir Zeit, Palestine.

Al-Sheikh, Radwan Fadl Al-Rahman et al. (2013). The phenomenon of divorce in the society of Medina: the causes, implications, and proposed solutions from the point of view of divorced people. Arab studies in education and psychology, 37(2), 211-260.

Al-Zahrani, Ali Mohammad Abdullah. (2021). Emotional divorce and its relationship both psychological stress and self-efficacy among a sample of couples in Jeddah. College of Social Work for Social Studies and Research, 23(2), 473-429.

Al-Zubaidi, Muhammad Omar et al. (2009). The Divorce Problem and Education Technology. Study under the supervision of Dr. Zakaria bin Yahya Lal, Training Courses Center, College of Education, Umm Al-Qura University, Makkah, Saudi Arabia.

Kheira, Obese. (2015). Self-image among children of divorce. Unpublished MA Thesis, Faculty of Humanities and Social Sciences, University of Mohamed Khaider, Biskra, Algeria.

Khudair, alqadi Maher Elyan. (2004). Divorce, the effects and disadvantages. Judge of the Sharia Court of Appeal, Palestinian National Information Center, Wafa, Gaza, Palestine.

Masoud, Mohamed Abdel Halim. (2013). Exercising a model of meaning therapy in the service of the individual to mitigate the damages resulting from divorce in the early stage of marriage. The 26th International Scientific Conference on Social Work, Part 6, pp. 2275-2285, Helwan University, Egypt.

Rababaa Omar Abdel-Rahim, \& Salem rafqat khulif. (2015). The reasons for divorce and the proposed solutions to deal with them from the point of view of divorced, divorced women, and Sharia judges in Jordan. College of Education Journal, 34(1620). Al-Azhar University, Egypt.

Shukry et al. (2011). Family Sociology. Dar Al-Masirah for Publishing, Distribution and Printing, Al-Abdali, 2nd floor, p. 68, Amman.

Teachman, J. D., \& Paasch, K. M. (1994). Financial Impact of Divorce on Children and Their Families. The Future of Children, 4(1), 63-83. https://doi.org/10.2307/1602478

Sebastian Valenzuela, Daniel Halpern, \& Katz James. (2014). Social network sites, marriage well-being and divorce Survey and state-level evidence from the United States. Computers in human behavior, 36, 94-101. https://doi.org/10.1016/j.chb.2014.03.034

Tarja K. Viitanen. (2014). The divorce revolution and generalized trust: Evidence from the United States 1973-2010. International review of law and economics, 38, 25-32. https://doi.org/10.1016/j.irle.2014.02.001

\section{Copyrights}

Copyright for this article is retained by the author(s), with first publication rights granted to the journal.

This is an open-access article distributed under the terms and conditions of the Creative Commons Attribution license (http://creativecommons.org/licenses/by/4.0/). 